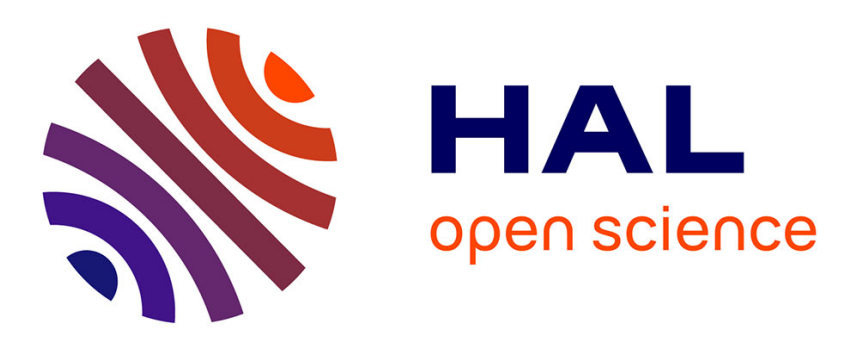

\title{
Business Participation to Global Biodiversity Governance: Challenging Theory with Empirical Data
}

\author{
Amandine Bled
}

\section{To cite this version:}

Amandine Bled. Business Participation to Global Biodiversity Governance: Challenging Theory with Empirical Data. Revista de Gestão Social e Ambiental, 2009, 3 (2), pp.75-91. halshs-00512394

\section{HAL Id: halshs-00512394 \\ https://shs.hal.science/halshs-00512394}

Submitted on 29 May 2019

HAL is a multi-disciplinary open access archive for the deposit and dissemination of scientific research documents, whether they are published or not. The documents may come from teaching and research institutions in France or abroad, or from public or private research centers.
L'archive ouverte pluridisciplinaire HAL, est destinée au dépôt et à la diffusion de documents scientifiques de niveau recherche, publiés ou non, émanant des établissements d'enseignement et de recherche français ou étrangers, des laboratoires publics ou privés. 


\title{
BUSINESS PARTICIPATION TO GLOBAL BIODIVERSITY GOVERNANCE: CHALLENGING THEORY WITH EMPIRICAL DATA
}

\section{Amandine Bled ${ }^{1}$}

\begin{abstract}
This article aims at questioning the way business representatives organise when confronted to the development of international environmental regulations. The negotiations of the Convention on biodiversity (CBD) are investigated as a case study. After examining the existing literature on business involvement in international biodiversity governance, the article elaborates on a database of business participation to CBD negotiations. The main aim, while using such a database, is to clarify theoretical hypotheses on business participation to environmental regimes as well as to propose new directions for further research on business actors in environmental governance. The first results from this quantitative assessment are discussed and complemented with qualitative data from the literature as well as a series of interviews and participatory observations. The article sheds some light on current trends in the participation of industries to international biodiversity policy-making. In particular, business actors are much more diversified than theoretical frameworks supposed them to be. The handful of individuals that initially represented business in biodiversity governance is nowadays being slowly replaced by a broader range of economic actors advocating new solutions for sustainable development. These actors act through national delegations as well as direct participation to the negotiations through individual firms or business coalitions. In order to take the diversity of business actors into account, the research calls for the development of more precise empirical assessments of business actors in environmental governance.
\end{abstract}

Keywords: International Environmental Negotiations; Global Biodiversity Governance; Business Participation.

\section{Resumo}

Após revisar a literatura existente sobre a participação de atores empresariais na governança internacional da biodiversidade, este artigo elabora uma base de dados sobre a participação desses atores durante as negociações da Convenção da Biodiversidade (CBD). Os resultados desta avaliação quantitativa são discutidos e complementados com dados qualitativos obtidos através de entrevistas e observações participantes. O objetivo principal é apresentar desafios teóricos e novos direcionamentos para futuras pesquisas sobre a participação do mundo dos negócios nos regimes ambientais internacionais.

Palavras-chave: Governança Ambiental Global; Biodiversidade; Participação de Atores Empresariais.

${ }^{1}$ Political Institute of Bordeaux, France. E-mail: a.bled@sciencespobordeaux.fr 


\section{INTRODUCTION: THE BUSINESS CASE FOR BIODIVERSITY GOVERNANCE}

The issue of the privatisation of governance is at the core of current studies in International Relations (IR) in general and environmental studies in particular. The concerns linked to the multiplication of private actors -Non Governmental Organisations (NGO), business actors, indigenous organisations- in a formerly state centred world system are indeed of great importance. However, while the role of environmental NGOs has been at the centre of environmental governance studies (see among others Princen \& Finger, 1994 ; Arts, 1998 ; Corell, 1999 ; Breitmeier \& Rittberger, 2000 ; Corell \& Betsill, 2001 ; Arts \& Mack, 2003), business actors have been somehow neglected by this same line of research (Levy \& Newell, 2005; Falkner, 2008).

Though, private sector actors' participation in environmental governance is of particular interest. On the one hand, there is a risk to see environmental regulations being bypassed by "business as usual" practices that might end up in "greenwashing"; on the other hand, private sector actors seem more and more to be part of the solution towards sustainable development through they involvement in environmental goals' achievement and their technological skills. In order to further analyse the links between business and environmental governance, this article aims at understanding the importance and characteristics of business actor's participation in international environmental negotiations. It takes the development of the biodiversity treaty adopted in 1992 under the United Nations Environment Program as an example.

According to some authors, the Convention on Biodiversity (CBD) has been "the first true sustainable development convention" (Le Prestre, 2002, p.1). Initially it was meant to deal with the conservation of biological diversity, but the scope of the agreement indeed evolved to cover issues such as biotechnology, intellectual property rights or technology transfer. This evolution was not predicted by the initiators of the biodiversity treaty -the United States helped by a coalition of northern environmental NGOs. The American government indeed declared during the Earth Summit in 1992 that the provisions of the biodiversity treaty had gone too far and had possible negative impacts on several international trade regimes. As a consequence, the American government, pushed by its industrial sectors concerned by the treaty, did not ratify the CDB. The status of the United States' as a non Party to the Biodiversity Convention has not prevented American participants from following carefully the CBD negotiations. In particular, the CBD negotiated two issues that have particular potential impacts for business activities.

In 2001, the Cartagena Protocol negotiated under the Convention has been the first international treaty to recognise the need for a precautionary approach to deal with the transboundary movements of genetically modified organisms. It has served as the basis for the elaboration of several national legislations on biosafety in countries such as Mexico, China or South Africa (Gupta \& Falkner, 2006). These developments have had a strong impact on biotechnology companies, grain traders and food retailers (Andrée, 2005).

The second issue dealt under the biodiversity treaty concerns the current negotiations of an international regime to regulate the access to natural genetic resources. In 1992, the biodiversity Convention recognised the sovereignty of nation states over their natural resources and put an end to the former "common heritage principle” that before 1992 stated that genetic resources were free of access for any 
users (Thomas, 2006). The rational for such a radical change in resources management was to try to redistribute part of the profits made from the commercialisation of genetic resources by-products -cosmetics, pharmaceuticals, seeds- to local and indigenous populations. In 2002, the Parties to the Convention decided that this objective had to be reinforced and adopted a mandate to establish a regime on Access and Benefit Sharing (ABS) by 2010. Pharmaceutical, nutraceutical, cosmetics or seed companies using biological resources as their raw material will be impacted by this new ABS scheme (Laird \& Wynberg, 2008).

The biodiversity treaty is no exemption to the research deficit we mentioned above on business participation to environmental regimes. When screening the literature on business and biodiversity, it appears that there is an overall lack of empirical analyses of economic actors in biodiversity governance. Interpretations mainly rely on structural deductive arguments presuming the way business is supposed to interact with biodiversity issues. Moreover, the literature often makes the methodological choice to focus on a limited number of business coalitions in order to picture the trends, positions and strategies of the entire business community. In the case of the biosafety negotiations, the Global Industry Coalition, an international business lobbying group, has been at the centre of academic studies (Andrée, 2005; Clapp, 2007; Buriel, 2007). This is even clearer when looking at the access and benefit sharing issue where the only business coalition mentioned in the literature has been the International Chamber of Commerce (Tully, 2003, p.84; Frein \& Meyer, 2005, p.123), while many other individual companies and groups are taking part to the negotiations (Bled, 2009a).

In order to fill this gap, this article aims at exposing the main results of an empirical assessment of business participation to biodiversity negotiations. This assessment is mostly based on quantitative data and proceeds as follows. The first part of the article questions the current theoretical frameworks that can help describing and explaining business participation to environmental regimes. While being relevant for understanding the particularities of business actors in environmental governance, these frameworks have important shortcomings. This leads us to propose an empirical assessment of business participation to the CBD negotiations. This assessment enables us to qualify former assumptions on business participation to environmental regimes as well as to propose several points for further research on the topic.

\section{FROM THEORY TO PRACTICE: STUDYING BUSINESS INVOLVEMENT IN ENVIRONMENTAL NEGOTIATIONS}

\section{a. Main theoretical approaches on business as an actor of environmental regimes}

A brief overview of former research on business power in IR and environmental governance helps us to understand the current elements at stake in the study of business as an actor in environmental negotiations. Former research has led to a better understanding of the components of business power at the international level as well as the nature of the political game business actors are evolving in. The structure/agency dilemma led to the development of two main theoretical approaches conceptualising the role of business actors in the policy-making processes.

A pluralist interpretation was initially developed in lobbying studies at the national level, in particular following the American tradition (Falkner, 2008, p.22). According to this approach, actors' interests are in competition to influence policy outcomes while no a priori dominance exists that can dictate power outcomes. Interests are indeterminate and evolve with time while their interactions shape the final policy results. This account favours relational power, a concept that refers to the Weberian 
tradition and identifies power as outcomes. Therefore, it considers a positivist epistemology researching for evidences of power through causal relations. However, scholars soon realised that causality was not always a precise phenomena and that invisible dimensions of power could also impact international politics. Power could be exercised outside of the visible sphere.

In the 1990s, International Political Economy (IPE) answered to the shortcomings of the pluralist assumptions by emphasizing on business structural power in world politics. This interpretation underlined the privileged relationship that business representatives had with policy-makers. By doing so, this account gave a deterministic view of international politics -as controlled by business interests- and privileged "structural power", a notion developed by Lucks and theorized by Strange (1988, p.24). Structural power was meant to picture, in an intuitive way, the different invisible components of power, contained in economic, financial, knowledge and security capacities. Again, the approach faced some limits, one of the most important ones being the absence of clear evidences of influence.

One of the main contributions of these two main approaches, and more particularly the structural one, has been to underline the importance of the material as well as ideational capacities of economic actors. Three main sources of power have indeed been identified by former research in order to explain firms' impact on international relations: relational power, structural power and discursive power -a third dimension at the crossroads between the other two (Fuchs, 2007; Fuchs \& Lederer, 2007).

However, these approaches have several shortcomings too. Mainly, by focusing on business skills and capacities, they tend to oversimplify the complexity of policymaking processes. Two recent trends in IR aim at balancing the pluralist and structural power perspectives, while integrating the three dimensions of business power: the neo-gramscian framework on the one hand and the business conflict school model on the other hand. Our next section is dedicated to these recent trends and develops their main assumptions on business actors' participation in environmental negotiations.

\section{b. Recent developments: the neo-gramscian approach and neo-pluralist model}

The neo-gramscian approach to global environmental governance and the neopluralist model both aim at synthesizing former research results on business power in environmental issues. These approaches can potentially help us to develop some hypotheses for our analysis of business actors in biodiversity negotiations.

Taking the structural approach on business power as a starting point, the neogramscian scholars centre they interpretation of international environmental politics on the notion of hegemony, defined as "[...] the persistence of specific social and economic structures that systematically advantage certain groups » (Levy \& Newell, 2005, p.86). Hegemony relies on three pillars of power - economic, organisational and discursive-, that are successively and alternatively employed by the actors engaged in policy-making (Levy \& Egan, 2003). According to neo-gramscian scholars this hegemony is currently embodied in transnational networks linking government officials with business actors and that advocate economic liberalisation to the detriment of environment standards.

While recognizing the privileged position of economic actors in current governance trends, neo-gramscian scholars aim also at describing the complexity of international relations' processes by describing the existence of countervailing forces to business interests, mainly NGOs and civil society (Levy \& Newell, 2005). The 
existence of a broad range of actors at the international level gives a contingent and contested nature to hegemony.

For the neo-gramscian trend, business dominance is seen as the "conventional wisdom" in biodiversity negotiations. Industries are expected to have great resources in the three pillars -economic, organisational and discursive- of hegemony. The common interest of business actors, aiming at maximising their profits, is also a crucial factor in determining their ability to influence the policy-making process. Several studies using the neo-gramscian assumptions have been conducted on the Cartagena Protocol negotiations. In these negotiations, "the position taken by industry players in the biosafety case did not divide along regional or country lines. Rather, industry groups presented a fairly unified position in the talks” (Clapp, 2007). The organisational structure of business at the international level is therefore considered as highly integrated (Andrée, 2005).

Regarding the influence of business actors on the negotiations, neo-gramscian scholars underline the fact that business actors have very close links with governmental officials. Neo-gramscian scholars indeed observe a phenomenon they call "revolving doors" and that describe the several changes in participants' status over the course of international decision-making processes, especially between government and private sector representatives (Newell \& Glover, 2003, p.13). Industry representatives are also meant to be integrated in national delegations to international negotiations.

Taking the pluralist account as a starting point, the business conflict school model -also labelled as neo-pluralism- tends to bring some elements of pluralism back in the business power debate, while recognising the diversity of business interests at the international level. It considers three potential divides between (i) international and national firms; (ii) technological leaders and technological laggards; (iii) firms operating at the beginning or at the end of the production chain (Falkner, 2008). These divides have consequences on the ability of business actors to organise at the international level and limit their influence on policy-making.

The business conflict school model therefore recognises a greater diversity of the business interests represented at the international level. Applied to the issue of biosafety, the business conflict school model signals that the so-called "business community" gathers a broad range of business sectors (Falkner, 2008, pp.32-35). Concerning the influence of these actors on international negotiation processes, the business conflict model recognises that private sector actors can act through national delegations -that will pursue different goals- as well as directly -through lobbying coalitions.

While giving us relevant elements on business power at the international level, the neo-gramscian and business conflict school models are still rather general on the modalities of business participation to environmental regimes. We argue in the next section that this lack of detail can be explained by their disregard of the micro-processes at stake for business participation to environmental governance. These interpretations indeed favour structural deductive argumentations. We underline in the next section the empirical elements that will be further studied in order to complement current assumptions on business participation to environmental regimes.

\section{c. Testing theoretical claims with quantitative data}

The neo-gramscian and business conflict school models present some common research questions that could be used to scrutinize more precisely business participation in the biodiversity treaty. 
First of all, they both consider the issue of business representation at the international level of policy-making. This point comprises the importance of business participation -i.e. the number of business representatives attending the negotiations- as well as the industrial sectors represented. Neo-gramscian scholars would expect a few number of industry representatives to participate at the international level of policymaking as business overall dominance at the international level renders any direct action unnecessary. According to these scholars, such data would have to be confronted to the number of NGO representatives that might counterbalance the overall structural power of industries. For the business conflict school model, the number of business representatives taking part to the negotiations is expected to be higher as business actors have to compete against each other to influence the policy process. The business conflict school model would also look at the different industrial sectors represented during the negotiations, a point neglected by the neo-gramscian framework. Though, both approaches elude the question of the origin of the firms involved in environmental negotiations. This point is crucial in order to understand the representativeness of business actors at the international level and will be scrutinised through our quantitative assessment of business participation.

Secondly, both frameworks try to reflect on business lobbying strategies at the international level. Neo-gramscian scholars underline the strong links uniting business representatives to national governments. On the contrary, the business conflict school model recognises that economic actors can interact directly in the negotiation processes. This point will have to be further analysed. In any case, both frameworks state that industries are fully aware of the negotiation processes and entirely devoted to influencing the debate. We will discuss this point by looking at the regularity of private sector actors' participation to the CBD negotiations.

Having evidenced these main research questions on business participation and business strategies, our analysis builds on a database of private sector representatives taking part to the CBD negotiations. We took down the institutional affiliation, the function, the country of origin as well as the industrial sector of each business participant to the negotiations. The analysis has been conducted for all the categories of CBD negotiations' meetings. The Parties to the Convention meet every two years during Conferences of the Parties (COP) to take the main decisions regarding the convention's activities ${ }^{2}$. Moreover, since 2004, the meetings of the Conference of the Parties to the Cartagena Protocol (COP-MOP) are organized back to back with these COP meetings. Before the adoption of the Protocol's text, negotiations were taking place in biosafety working groups (BSWG and ExCOP meetings) and until its entry into force in intergovernmental committees (ICCP meetings). Specific questions have also regularly been discussed in expert group meetings (B-ExG). The access and benefit sharing negotiations have been following the same negotiation processes with working groups (WGABS meetings) and expert meetings (ABS-ExG).

Table 1. Summary of the negotiation meetings constituting the database

\begin{tabular}{|c|c|c|c|}
\hline COP & ICCP & COP MOP & BSWG \\
\hline $\begin{array}{c}\text { Conference of } \\
\text { the Parties }\end{array}$ & $\begin{array}{c}\text { Intergovernmental } \\
\text { committee for the }\end{array}$ & $\begin{array}{c}\text { Conference of the Parties } \\
\text { serving as a meeting for the }\end{array}$ & $\begin{array}{c}\text { Biosafety working } \\
\text { groups }\end{array}$ \\
\hline
\end{tabular}

\footnotetext{
${ }^{2}$ A methodological note at the end of the article explains in more details the origin of the data as well as the analysis conducted. Data were not available for the COP3 meeting.
} 


\begin{tabular}{|c|c|c|c|}
\hline & Protocol & Protocol & \\
\hline $1992-2008$ & $2000-2002$ & $2004-2008$ & $1996-2000$ \\
\hline 8 & 3 & 4 & 10 \\
\hline
\end{tabular}

\begin{tabular}{|c|c|c|}
\hline Ex BS & Ex ABS & WGABS \\
\hline $\begin{array}{c}\text { Biosafety expert } \\
\text { groups }\end{array}$ & $\begin{array}{c}\text { Access and benefit } \\
\text { sharing expert groups }\end{array}$ & $\begin{array}{c}\text { Working groups on access and } \\
\text { benefit sharing }\end{array}$ \\
\hline $2000-2008$ & $1999-2007$ & $2001-2008$ \\
\hline 34 & 7 & 6 \\
\hline
\end{tabular}

The literature review on business power made above reveals that the quantitative results obtained from the database have to be considered and discussed carefully. Qualitative data -from a series of around 40 interviews with key state and non state actors in the CBD negotiations and participatory observations- are consequently added to the quantitative assessment in order to shed some lights on current trends in biodiversity negotiations. The next section of the article develops the nature of business representation in biodiversity negotiations (section $2 \mathrm{a}$ ) and then analyses the strategies of private sector actors during the negotiations (section $2 \mathrm{~b}$ ).

\section{AN EMPIRICAL ASSESSMENT OF BUSINESS PARTICIPATION AND BUSINESS STRATEGIES}

\section{a. Importance of business participation to biodiversity negotiations}

This section aims at analysing the importance of business participation to biodiversity negotiations as well as the characteristics -sector and origin- of the firms taking part to the CBD's meetings.

Table 2 presents the participation of industry representatives in CBD meetings compared to NGOs, indigenous groups and government representatives' involvement.

Table 2. Non state actors' comparative involvement in biodiversity governance (in percentage, compared to number of governmental delegates).

\begin{tabular}{|l|c|c|c|c|c|c|}
\hline & COP & ICCP & BSWG & BS-ExG & WGABS & ABS-ExG \\
\hline ENGOs & 29 & 17,74 & 12 & 4,3 & 11,25 & 3,1 \\
\hline Indigenous & 4,78 & 0 & 0 & 0 & 11,58 & 1,8 \\
\hline Business & 3,77 & 6,57 & 10,81 & 7,9 & 7,21 & 5,3 \\
\hline
\end{tabular}

Table 2 shows that a relatively small number of business participants have taken part to the CBD negotiation meetings. During the COP meetings, the private sector represents less than $4 \%$ of the number of governmental officials. The participation of ENGO's is nearly ten times higher. The participation of business actors tend to be more important during expert group meetings. When looking at the involvement of business actors over time, we can also note that the number of private sector representatives taking part to the negotiation meetings grew with time, just as did the number of ENGO's and indigenous' peoples organisations. The progression of indigenous organisations is the most sticking feature when we look at the evolution of non-state actors' participation to CBD meetings.

A neo-gramscian interpretation of these results would lead us to conclude that business has a great power in biodiversity governance. Firms, protected by their 
national governments, do not have to engage in lobbying while numerous ENGOs try to intervene as countervailing forces in the process. The power of business would be confirmed by the dominance of business actors in expert meetings. However, a further analysis of the reasons behind the low participation of business actors to the negotiations reveals that it can be explained by at least three factors.

First of all, industry members became aware quite late of the biodiversity regime. At the beginning of the biosafety negotiations, the wide range of topics raised in the CBD meetings worked as a disincentive for business participation (Reifschneider, 2002). For most of the private sector representatives we interviewed, the initial indifference of business actors towards the CBD has been one of their main mistakes that later led to the adoption of a biosafety protocol in contradiction to biotechnology firms' interests. Secondly, business actors are usually active on precise topics and only follow the negotiations that might have an impact of their activities. On the contrary, NGOs can pursue a much broader goal and be present at more meetings. Participation can be a potential risk for industries as they can become the preferential targets of environmental groups (interview with representative from CropLife International, 14/05/2008). Thirdly, business actors preferred to rely on their national delegations and decided not to participate directly in the negotiations (interview with European seed company, 24/03/2006). The last two factors are compatible with a neo-gramscian perspective on business power in environmental governance. However, the third factor qualifies former claims on business "obvious” awareness and control of environmental issues.

A second parameter of business participation to the CBD negotiations is linked to the industrial sectors represented at the international level. Table 3 illustrates the range of industrial sectors involved in the CBD negotiations.

Table 3. Most significant industrial sectors represented in CBD meetings (in percentage, indicated for figures greater than 3\%).

\begin{tabular}{|l|c|c|c|c|c|c|c|}
\hline & COP & COPMOP & ICCP & BSWG & BS-ExG & WGABS & ABS-ExG \\
\hline Pharmaceuticals & $\mathrm{X}$ & $\mathrm{X}$ & $\mathrm{X}$ & 7 & $\mathrm{X}$ & 25 & 15 \\
\hline Cosmetics & 3 & $\mathrm{X}$ & $\mathrm{X}$ & $\mathrm{X}$ & $\mathrm{X}$ & $\mathrm{X}$ & $\mathrm{X}$ \\
\hline $\begin{array}{l}\text { Environmental } \\
\text { services }\end{array}$ & 4 & $\mathrm{X}$ & $\mathrm{X}$ & $\mathrm{X}$ & $\mathrm{X}$ & 4 & 10 \\
\hline Seeds & 9 & 14 & 30 & 32 & 18 & 19 & 25 \\
\hline Biotechnology & 9 & 37 & 41 & 34 & 54 & 34 & 30 \\
\hline Grain traders & $\mathrm{X}$ & 12 & 15 & 7 & 22 & $\mathrm{X}$ & $\mathrm{X}$ \\
\hline Oil & 11 & $\mathrm{X}$ & $\mathrm{X}$ & $\mathrm{X}$ & $\mathrm{X}$ & $\mathrm{X}$ & $\mathrm{X}$ \\
\hline Consultancy & 4 & $\mathrm{X}$ & 9 & 11 & $\mathrm{X}$ & $\mathrm{X}$ & $\mathrm{X}$ \\
\hline Multi-sectors & 22 & 23 & $\mathrm{X}$ & 3 & $\mathrm{X}$ & 11 & 10 \\
\hline
\end{tabular}

The diversity of sectors represented is particularly relevant during Conferences of the Parties. Expert meetings or working group tend rather to gather sectors specialised in seed production, seed transportation and biotechnology for biosafety and seed production, biotechnology and pharmaceuticals for access and benefit sharing. Analysed carefully, the data tend to validate the business conflict school model. For biosafety, different firms positioned along the seeds production chain are present to the negotiations. For ABS, the companies taking part to the negotiations all have a specific use of genetic resources. Conflicts are likely to arise among these firms as they pursue different objectives. During COP meetings, environmental services companies are pushing for strong environmental norms while biotechnology companies favour low environmental standards. 
Table 3 is important for the elements it illustrates but also for revealing the sectors that are surprisingly poorly involved in the negotiations. Natural products companies for instance are directly targeted by ABS regulations as they use innovations developed from natural resources as their main source of profit. Their absence in the CBD meetings can be explained by the highly political atmosphere of ABS meetings where claims of "biopiracy" ${ }^{3}$ by NGOs and indigenous organisations are strong (interview with bioprospecting company, 21/03/2006). Moreover, several business activities are so much linked to national and local practices that it might also be difficult for firms to find a common interest in collective action at the international level.

A third characteristic of business participation to CBD meetings relates to the origin of business representatives. Table 4 illustrates the country of origin of business actors taking part to CBD meetings. Whereas former approaches on business power tended to neglect this dimension of business participation, the analysis of business origin reveals several trends in business representation at the international level.

By considering the overall proportion of business representatives according to their origin, we can observe the dominance of North American companies -from Canada and the United States- in biodiversity negotiations. This proportion questions the usual claims of all major business associations that assert to be highly representative of the entire business community. For instance, the Global Industry Coalition, the main business coalition involved in the biosafety negotiations, claims to represent more than 2200 members in 130 countries worldwide while the private sector representatives registering under its name mostly come from North America.

Table 4. Percentage of industry representatives by country of origin

\begin{tabular}{|l|c|c|c|c|c|c|c|}
\hline & COP & COPMOP & ICCP & BSWG & BS-ExG & WGABS & ABS-ExG \\
\hline Belgium & 6 & 9 & 5 & 8 & 13 & 11 & $\mathrm{X}$ \\
\hline Brazil & 25 & 32 & $\mathrm{X}$ & $\mathrm{X}$ & $\mathrm{X}$ & 7 & $\mathrm{X}$ \\
\hline Canada & 4 & 6 & 9 & 19 & 12 & 6 & 17 \\
\hline Denmark & 0 & 0 & $\mathrm{X}$ & $\mathrm{X}$ & $\mathrm{X}$ & $\mathrm{X}$ & 17 \\
\hline Germany & 13 & 6 & 5 & 3 & $\mathrm{X}$ & $\mathrm{X}$ & 11 \\
\hline Japan & 7 & 0 & $\mathrm{X}$ & $\mathrm{X}$ & $\mathrm{X}$ & 11 & 11 \\
\hline Malaysia & 6 & 0 & $\mathrm{X}$ & $\mathrm{X}$ & $\mathrm{X}$ & $\mathrm{X}$ & $\mathrm{X}$ \\
\hline Mexico & 0 & 4 & 3 & 4 & 3 & $\mathrm{X}$ & $\mathrm{X}$ \\
\hline Netherlands & 6 & $\mathrm{X}$ & 9 & 4 & 3 & 6 & 6 \\
\hline Pakistan & $\mathrm{X}$ & $\mathrm{X}$ & $\mathrm{X}$ & $\mathrm{X}$ & $\mathrm{X}$ & $\mathrm{X}$ & 6 \\
\hline South Africa & $\mathrm{X}$ & $\mathrm{X}$ & 3 & $\mathrm{X}$ & $\mathrm{X}$ & $\mathrm{X}$ & $\mathrm{X}$ \\
\hline Spain & $\mathrm{X}$ & $\mathrm{X}$ & & $\mathrm{X}$ & $\mathrm{X}$ & 7 & $\mathrm{X}$ \\
\hline Sweden & $\mathrm{X}$ & $\mathrm{X}$ & 3 & $\mathrm{X}$ & $\mathrm{X}$ & $\mathrm{X}$ & $\mathrm{X}$ \\
\hline Switzerland & 5 & $\mathrm{X}$ & 6 & 4 & $\mathrm{X}$ & 10 & 6 \\
\hline United & 6 & $\mathrm{X}$ & 5 & $\mathrm{X}$ & 4 & 3 & $\mathrm{X}$ \\
Kingdom & & & & & & & \\
\hline United States & 12 & 26 & 37 & 49 & 44 & 35 & 28 \\
\hline
\end{tabular}

After North America, developed countries -Belgium, Denmark, Japan, United Kingdom, etc.- are overrepresented. The figures also demonstrate the importance of the meetings' venue in determining companies' attendance. For instance, $82 \%$ of business

\footnotetext{
${ }^{3}$ That is to say the misappropriation of natural resources and/or traditional knowledge.
} 
representatives taking part to the COP 8 meeting in Brazil came from this country. Table 5 illustrates the figures obtained if we eliminate this distortion for COP meetings.

Table 5. Percentage of industry representatives by country of origin, excluding COP host country.

\begin{tabular}{|l|c|c|c|c|c|c|c|c|}
\hline & COP1 & COP2 & COP4 & COP5 & COP6 & COP7 & COP8 & COP9 \\
\hline Belgium & $\mathrm{X}$ & 6 & $\mathrm{X}$ & 17 & $\mathrm{X}$ & 19 & 12 & 12 \\
\hline Brazil & $\mathrm{X}$ & $\mathrm{X}$ & $\mathrm{X}$ & $\mathrm{X}$ & 13 & 6 & $\mathrm{XXX}$ & 5 \\
\hline Canada & $\mathrm{X}$ & 31 & 32 & 17 & 7 & 13 & 8 & $\mathrm{X}$ \\
\hline China & $\mathrm{X}$ & $\mathrm{X}$ & $\mathrm{X}$ & $\mathrm{X}$ & $\mathrm{X}$ & 6 & $\mathrm{X}$ & $\mathrm{X}$ \\
\hline Colombia & $\mathrm{X}$ & $\mathrm{X}$ & $\mathrm{X}$ & $\mathrm{X}$ & $\mathrm{X}$ & $\mathrm{X}$ & 4 & $\mathrm{X}$ \\
\hline Denmark & 9 & $\mathrm{X}$ & $\mathrm{X}$ & $\mathrm{X}$ & $\mathrm{X}$ & $\mathrm{X}$ & $\mathrm{X}$ & $\mathrm{X}$ \\
\hline Finland & $\mathrm{X}$ & $\mathrm{X}$ & $\mathrm{X}$ & $\mathrm{X}$ & 7 & $\mathrm{X}$ & $\mathrm{X}$ & $\mathrm{X}$ \\
\hline France & $\mathrm{X}$ & $\mathrm{X}$ & $\mathrm{X}$ & $\mathrm{X}$ & 7 & $\mathrm{X}$ & $\mathrm{X}$ & $\mathrm{X}$ \\
\hline Germany & $\mathrm{X}$ & $\mathrm{X}$ & 5 & 8 & $\mathrm{X}$ & $\mathrm{X}$ & $\mathrm{X}$ & $\mathrm{XXX}$ \\
\hline Japan & $\mathrm{X}$ & $\mathrm{X}$ & $\mathrm{X}$ & $\mathrm{X}$ & 7 & 19 & $\mathrm{X}$ & 20 \\
\hline México & $\mathrm{X}$ & $\mathrm{X}$ & $\mathrm{X}$ & 8 & $\mathrm{X}$ & $\mathrm{X}$ & $\mathrm{X}$ & $\mathrm{X}$ \\
\hline Netherlands & $\mathrm{X}$ & $\mathrm{X}$ & $\mathrm{X}$ & $\mathrm{X}$ & $\mathrm{XXX}$ & 13 & 12 & 6 \\
\hline Norway & $\mathrm{X}$ & $\mathrm{X}$ & $\mathrm{X}$ & $\mathrm{X}$ & $\mathrm{X}$ & $\mathrm{X}$ & 4 & $\mathrm{X}$ \\
\hline Peru & $\mathrm{X}$ & $\mathrm{X}$ & $\mathrm{X}$ & $\mathrm{X}$ & $\mathrm{X}$ & $\mathrm{X}$ & 4 & $\mathrm{X}$ \\
\hline Switzerland & $\mathrm{X}$ & $\mathrm{X}$ & 11 & 8 & 7 & 6 & 8 & 11 \\
\hline $\begin{array}{l}\text { United } \\
\text { Kingdom }\end{array}$ & $\mathrm{27}$ & 19 & 21 & 25 & 7 & 6 & 12 & 6 \\
\hline United States & $\mathrm{64}$ & 44 & 32 & 17 & 47 & 13 & 31 & 9 \\
\hline Zimbabwe & $\mathrm{X}$ & $\mathrm{X}$ & $\mathrm{X}$ & $\mathrm{X}$ & $\mathrm{X}$ & $\mathrm{X}$ & 4 & $\mathrm{X}$ \\
\hline
\end{tabular}

In Table 5, the dominance of North American companies in the negotiation process is even clearer. This point raises a characteristic that has been somehow neglected by former studies on business participation, that is to say that participation can be an issue for industry representatives as well. Participation indeed means possessing the required skills to follow the main points of the negotiations. Most industry representatives taking part to CBD meetings explained they had to convince their own company to participate in meetings, as such participation requires financial support and time. A wide range of international negotiations, of which the biodiversity discussions are just one example, can have potential impacts on the economic activities of industries. This reduces their capacities to participate in negotiation meetings especially in the case of small and medium size companies or firms from developing countries- and result in the main mobilisation of political, powerful lobbying coalitions from developed countries.

Moreover, the participation of developing countries' companies is sometimes manipulated by transnational corporations. For instance, Monsanto, the firm that has been the most virulently criticised for its stubbornness during the negotiations of the Cartagena Protocol, sent two representatives from South Africa and Kenya to the ICCP2 meeting, after the adoption of the protocol's text, in order to reinforce its legitimacy.

When looking at the evolution of business representation during COP meetings, Table 5 reveals that business representativeness is improving over time. The first COP was attended only by Dutch, English and American companies. Nowadays Brazilian 
companies' participation is a sign of a better participation of developing countries. The article now turns to the analysis of business strategies in environmental regimes.

\section{b. Firms as political actors in biodiversity governance}

Several options exist for industry representatives to take part to international negotiations: they might ask to be involved as observers or to be integrated in national delegations. In both cases they can choose to participate as a firm or as a member of an industrial association. Associations are indeed perceived by non state actors as been the most adequate structures to attract the attention of delegates.

We have seen in the first part of the article that, for neo-gramscian scholars, business actors are believed to be taking part to national delegations. In particular, "revolving doors" are an illustrative phenomenon of the strong links that unite business and governmental officials in their common interest for flexible environmental regulations. Though, Table 6 helps us to qualify the overall importance of business representation in national delegations. In nearly all categories of meetings, less than $10 \%$ of private sector actors taking part to the negotiations are integrated in national delegations. The ABS-ExG groups are the only exception to this ratio with as many business actors involved in national delegations as in direct action. However, expert groups usually accept a limited number of observers. This can partially explain why the proportion of business actors in delegations is, in comparison, higher.

Table 6. Percentage of private sector representatives’ institutional affiliation

\begin{tabular}{|l|c|c|c|c|c|c|c|}
\hline & COP & COPMOP & ICCP & BSWG & $\begin{array}{l}\text { BS- } \\
\text { ExG }\end{array}$ & WGABS & $\begin{array}{l}\text { ABS- } \\
\text { ExG }\end{array}$ \\
\hline Association & 47 & 78 & 59 & 51 & 79 & 61 & 20 \\
\hline $\begin{array}{l}\text { National } \\
\text { delegation }\end{array}$ & 8 & 13 & 5 & 8 & 9 & 18 & 50 \\
\hline $\begin{array}{l}\text { Individual } \\
\text { company }\end{array}$ & 45 & 9 & 36 & 41 & 12 & 21 & 30 \\
\hline
\end{tabular}

National delegations to CBD meetings are mostly composed by environmental, development and agriculture ministries. In some cases, the participation of private sector actors to national delegations is balanced by the presence of NGOs (Rosendal, 2006, p.272). These elements reinforce the loose relationship between national delegations and industrial interests. Moreover, the presence of private actors in delegations is not necessarily a sign of poor environmental awareness but can reveal some particularly strong national legislation related to the CBD's objectives. For instance, the Brazilian delegation to ABS meetings comprises members from Brazilian cosmetic firms such as Natura. In 2003, the Brazilian government put in place a binding ABS legislation involving all stakeholders in decision-making related to the access to Brazilian natural genetic resources. Nowadays, Brazilian firms are therefore promoting the adoption of these binding rules at the international level.

"Revolving doors" are relatively rare in biodiversity negotiations. In line with the neo-gramscian argument, they mark some important turns in the negotiations. For instance, our interviews and observations revealed that Val Giddings, who used to be in the American delegation, joined the business community during the Cartagena Protocol negotiations in order to create the first international business coalition dedicated to biosafety: the Global Industry Coalition. Alwin Kopse, a former Swiss delegate at the initiative of the voluntary Bonn guidelines for access to genetic resources that were adopted by the Parties to the Convention in 2001, joined the International Chamber of 
Commerce task force on ABS just after the adoption of Bonn agreement. In both cases, these individuals were advocating flexible international standards.

Table 6 illustrates that the main channel of influence favoured by business actors relies on business associations. When screening the name of the organisations involved in biodiversity negotiations -the Pharmaceuticals Researchers and Manufacturers of America, EuropaBio, the International Chamber of Commerce, etc.- it becomes visible that these associations are not specifically dedicated to biodiversity governance. They mostly consist in professional coalitions that are usually representing business in commercial negotiations. These groups are therefore poorly specialised in environmental negotiations.

Finally, a few companies prefer to participate individually to the meetings. This underlines that collective action is not necessarily easy for business representatives that might be competitors. It can also signal the preference of certain groups to remain differentiated from their homologues. For instance, Novo Nordisk, a Dutch biotechnology company specialised in enzymes was the only company not joining the Biotechnology Industry Organisation initiative during the Cartagena protocol negotiations and did not join the Global Industry Coalition later on. This is due to its particular interest in biodiversity and a moderate corporate policy ${ }^{4}$. On the contrary, Monsanto deliberately lobbied for its own interests and periodically sent its own representatives to the negotiations. After the elaboration of the protocol text that represented a great failure for the biotechnology company, the strategy of the firm changed and Monsanto became mainly represented through the International Chamber of Commerce -or by southern representatives as noticed above.

Private sector actors' presence in meetings is one aspect of business involvement in negotiations. Environmental negotiations are however well known to be complex and to gather a great number of different interests and actors (Chasek, 2001). In such a complex environment, the experience participants have of former negotiations can make a great difference for the progress of the debates (Tolba \& Rummel-Bulska, 1998; Chasek, 2001; Depledge, 2006). This is one aspect of business participation that has been poorly studied so far.

The tables 7 to 9 present the number of CBD meetings attended by each private sector representative. The data illustrates that very few private sector actors followed more than one negotiation meeting.

Table 7. Number of CBD meetings attended by each business representative

\begin{tabular}{|l|c|c|c|c|c|c|c|c|c|}
\hline & 1 & 2 & 3 & 4 & 5 & 6 & $7-10$ & $11-20$ & $\begin{array}{c}\text { More than } \\
20\end{array}$ \\
\hline $\begin{array}{l}\text { Number of business } \\
\text { representatives }\end{array}$ & 633 & 96 & 30 & 20 & 12 & 8 & 12 & 11 & 1 \\
\hline
\end{tabular}

Table 8. Number of biosafety meetings attended by each business representative

\begin{tabular}{|l|c|c|c|c|c|c|c|c|}
\hline & 1 & 2 & 3 & 4 & 5 & 6 & $7-10$ & More than 10 \\
\hline $\begin{array}{l}\text { Number of } \\
\text { business } \\
\text { representatives }\end{array}$ & 270 & 46 & 15 & 13 & 9 & 5 & 12 & 5 \\
\hline
\end{tabular}

\footnotetext{
${ }^{4}$ In ABS governance, Novo Nordisk was the first company to establish guidelines on the access to genetic resources. See also (Frein \& Meyer, 2008, p.157).
} 
Table 9. Number of working group on access and benefit sharing attended by each business representative

\begin{tabular}{|l|c|c|c|c|c|}
\hline & 1 & 2 & 3 & 4 & 5 \\
\hline $\begin{array}{l}\text { Number of business } \\
\text { representatives }\end{array}$ & 43 & 9 & 8 & 4 & 2 \\
\hline
\end{tabular}

When looking at percentages, the number of private sector representatives attending only one CBD meeting represents more than $3 / 4$ of private sector actors. This lack of continuity in the participation of business representatives can be explained by their lack of understanding of the negotiation process. For instance, most private sector participants to the ABSWG4 meeting were heavily surprised by the uncertainty surrounding the status of a draft proposal for an international regime elaborated and proposed by the Parties to the African group. Most industry representatives were complaining about the lack of clarity of the negotiation process compared to the one of trade negotiations that they usually attend.

However, the tables 7 to 9 also demonstrate that a handful of individuals have been highly involved in CBD meetings. These individuals' presence has been crucial in organising private sectors' actions in biodiversity governance. Laura Reifschneider that attended 29 CBD meetings explains how she took part to the formation of a business coalition under the banner of the Biotechnology industry Organisation (BIO) during the Cartagena protocol negotiations (Reifschneider, 2002). Val Giddings, vice president of BIO that attended 11 CBD meetings has been pointed by several interviewees as the "founding father" of the Global Industry Coalition, one of the most powerful business coalitions in the Cartagena Protocol negotiations.

The creation, evolution and strategies of lobbying groups in biodiversity governance such as the Global Industry Coalition or the Bioindustry Organisation (BIO), have been mentioned in the literature as a sign of strong business coordination during the negotiations (Clapp, 2007). Our analysis reveals that these coalitions rely on a limited number of active participants. In practice and as already mentioned, business participants continue to favour other kind of representation -such as individual involvement. A deeper analysis of the way business international coalitions function reveals that their main role consist in information sharing and socialisation (Bled, 2009b). The Global Industry Coalition has mainly been the results of the efforts of a handful of North-American representatives particularly opposed to the Cartagena Protocol (interview with European seed company, 24/03/2006). The relatively low strategic role of business coalitions in the biodiversity political arena is confirmed by the common objective among private sector representatives to lobby in priority for their own companies.

\section{CONCLUSION: CALLING FOR FURTHER EMPIRICAL RESEARCH ON BUSINESS PARTICIPATION TO ENVIRONMENTAL REGIMES}

The quantitative analysis of private sector representatives' involvement in the CBD negotiations conducted in this article helps us to understand the way business organises when confronted to international environmental policy-making. Our starting 
point was to elaborate on theoretical assumptions on business participation to environmental regimes in order to detail the modalities of such participation.

The neo-gramscian interpretation of business power in international negotiations is only partially validated by our analysis. While business actors are to some extent included in national delegations, several signs are qualifying their overall influence in the policy process. In particular, the high number of business representatives participating as observers, the broad range of business sectors represented and the low involvement of private sector actors contradict the vision of business actors as obvious political actors. Some of these elements -such as the broad range of industrial sectors represented but also the multiple origins of the firms- tend to rather validate the business conflict school model.

However, the analysis also illustrates several new aspects of business participation to environmental regimes that have been somehow neglected by former studies. The article highlights the fact that business actors are mainly affiliated to NorthAmerican associations. This element tackles the issue of developing countries and small and medium size companies' capacities to intervene in the negotiations process. The results also show the lack of involvement of private sector actors, which mobilisation mainly relies on a handful of individuals, mostly opposed to environmental regulations. Business associations taking part to the CBD meetings are poorly specialised in environmental issues.

This trend might be subject to changes as the awareness of private sector actors towards biodiversity governance is improving. Current efforts by the Parties to the Convention are oriented towards the further involvement of all private sector representatives in CBD activities. These efforts translated during COP8 in a new decision, decision VIII/17, furthering business involvement in the activities of the biodiversity Convention (Bled, 2009a). The example of Brazilian companies' participation to the negotiations as well as their integration in their national delegation is another sign for potential change.

In relation to the academic debate on business power in environmental governance, our study calls for a better empirical analysis of firms' participation to environmental regimes. Such analyses will have to picture more precisely the broad diversity of business actors involved in the debate. The issue of the firm as a political actor will also have to be questioned. In order to do so, the empirical scrutiny of business coalitions' function could be an important step forward.

\section{Note on the methodology used for the data analysis}

In order to conduct the quantitative assessment that serves as a basis for this article, the author gathered all the lists of participants to the CBD meetings. Several of these lists were made available by the CBD Secretariat and the remaining lists were collected by the author by the archives of Ecoropa, a German environmental non governmental organization that followed the CBD negotiations, as well as among the documents of Hartmut Meyer, an expert on biosafety issues.

The author then identified on these lists all the private sector representatives that took part to the CBD negotiations. For each negotiation meeting, the characteristics of all business representatives - their origin, industrial sector and affiliation - have then been coded by the author in order to carry out a statistical analysis of their content.

\section{Acknowledgements}

An initial draft of this paper has been presented to the Oslo PhD School on "Business and Global Governance for Sustainable Development”, Oslo University, 14-16 April. I would like to thank Prof. Robert Falkner as well as all the participants to this workshop 
for their useful comments. I also would like to express my regards to the editing team and reviewers of the Brazilian RGSA journal.

Moreover, the statistical analysis presented in this paper would never have been conducted in such a detailed way without the assistance of Dr. Marco Orsini, Icced (Institut de Conseil en Environnement et Développement Durable), Belgium.

Though, all the remaining errors are the sole responsibility of the author.

\section{REFERENCES}

ANDRÉE, P. The Genetic Engineering Revolution in Agriculture and Food: Strategies of the 'Biotech Bloc'. In D.L. Levy \& P.J. Newell (Eds.), The Business of Global Environmental Governance, (pp. 135-166). Cambridge: MIT Press, 2005.

ARTS, B. The Political Influence of Global NGOs. Utrecht: International Books, 1998.

ARTS, B., \& Mack, S. Environmental NGO's and the biosafety protocol: a case study on political influence. European Environment, 13, 2003, p.19-33.

BLED, A.J. Business to the rescue: private sector actors and global environmental regimes' legitimacy. International Environmental Agreements: Politics, Law and Economics, 9, 2009a, p.153-171.

BLED, A.J. Organising Interests: International Business Coalitions in Environmental Governance. Paper presented at the International Studies Association annual Convention, New York, $18^{\text {th }}$ February 2009, 2009b

BREITMEIER, H. \& RITTBERGER, V. Environmental NGOs in an Emerging Global Civil Society. In P.S. Chasek, (Ed.), The Global Environment in the Twenty-First Century: Prospects for International Cooperation.Tokyo: United Nations University Press, 2000, p. 130-163.

BURIEL, S. W. Non state actors and the Cartagena Protocol on Biosafety. In M. M. Betsill \& E. Corell (Eds.), NGO diplomacy The Influence of Nongovernmental Organizations in International Environmental Negotiations, MIT Press, 2007.

CHASEK, P. S. Earth negotiations, Analysing thirty years of Environmental Diplomacy, Tokyo, The United Nations University, 2001.

CLAPP, J. Transnational Corporate Interests in International Biosafety Negotiations. In R. Falkner (Ed.), The international politics of genetically modified food: diplomacy, trade, law, Palgrave Macmillan, 2007.

CORELL, E. Non-State Actor Influence in the Negotiations of the Convention to Combat Desertification. International Negotiation, 4(2), 1999, p.197-223.

CORELL, E. \& BETSILL, M. M. A Comparative Look at NGO Influence in International Environmental Negotiations: Desertification and Climate Change. Global Environmental Politics, 1 (4), 2001, p.86-107. 
DEPLEDGE, J. The Opposite of Learning: Ossification in the Climate Change Regime. Global Environmental Politics, 6 (1), 2006, p.1-22.

FALKNER, R. Business Power and Conflict in International Environmental Politics, Palgrave MacMillan, 2008.

FREIN, M. \& MEYER. H. The concept of benefit-sharing: A step forward or backward?" p121-162, in Burrows Beth (ed.), The Catch: Perspectives in Benefit Sharing,The Edmonds Institute, 2005.

FUCHS, D. Business Power in Global Governance, Lynne Rienner Publishers Inc, 2007.

FUCHS, D. \& LEDERER, M.L. The Power of Business. Business and Politics, 9 (3), 2007, p.1-17.

GUPTA, A. \& FALKNER R. The Influence of the Cartagena Protocol on Biosafety: Comparing Mexico, China and South Africa. Global Environmental Politics, 6 (4), . 2006.

LAIRD S. \& WINBERG R. Access and Benefit sharing in practice: trends in partnerships across sectors. CBD Technical Series n³8, 2008.

LE PRESTRE, P. G. Introduction: the Emergence of Biodiversity Governance. In P. Le Prestre (Ed.), pp.1-7, Governing Global Biodiversity, Aldershot: Ashgate, 2002.

LEVY, D. L. \& Egan, D. A Neo-Gramscian Approach to Corporate Political Strategy: Conflict and Accommodation in the Climate Change Negotiations. Journal of Management Studies, 40(4), 2003, p.803-829.

LEVY, D. \& Newell, P. A Neo-Gramscian Approach to Business in International Environmental Politics: An Interdisciplinary, Multilevel framework. In D. Levy \& P. Newell (Eds) The Business of Global Environmental Governance, MIT Press, 2005.

NEWELL P. \& GLOVER D. Business and biotechnology: regulation and the politics of influence. Institute of Development Studies, Working Paper 192, 2003.

PRINCEN, T. \& FINGER, M. Environmental NGOs in World Politics: Linking the Local and the Global. London, New York: Routledge, 1994.

REIFSCHNEIDER, L. M. Global Industry Coalition. In C. Bail, R. Falkner \& H. Marquard (Dir), ? pp.273-277, The Cartagena Protocol on Biosafety. Reconciling Trade in Biotechnology with Environment and Development, London: Earthscan and the Royal Institute of International Affairs, 2002.

ROSENDAL K. G. Regulating the Use of Genetic Resources - Between International Authorities. European Environment, 16, 2006, p.265-277.

STRANGE, S. States and Markets, London: Pinter, 1988. 
THOMAS, F. Biodiversité, biotechnologies et savoirs traditionnels. Du patrimoine commun de l'humanité aux ABS (Access to Genetic Resources and Benefit-Sharing). Revue Tiers Monde, 188, 2006, p.825-842.

TOLBA, M. K. \& Rummel-Bulska I. Global environmental diplomacy: negotiating environmental agreements for the world, 1973-1992, Cambridge (MA): MIT press, 1998.

TULLY S. The Bonn Guidelines on Access to Genetic Resources and Benefit Sharing. RECIEL 12 (1), 2003, p.84-98. 